\title{
IN VITRO ANTIOXIDANT AND PHYTOCHEMICAL ANALYSIS OF DIFFERENT PARTS OF SIMANA LAGI APPLE ([MALUS DOMESTICA BORKH.] "SIMANA LAGI") GROWN IN EAST JAVA-INDONESIA
}

\author{
IRDA FIDRIANNY*, DHELLA FITRANI, SITI KUSMARDIYANI, DEFRI RIZALDY, KOMAR RUSLAN
}

Department of Pharmaceutical Biology, School of Pharmacy, Bandung Institute of Technology, Indonesia. Email: irdafidrianny@gmail.com

Received: 12 June 2017, Revised and Accepted: 10 July 2017

\section{ABSTRACT}

Objectives: The goals of this research were to observe antioxidant properties from different parts of Simana lagi apple ([Malus domestica Borkh.] "Simana lagi") using two antioxidant testing methods which were 2,2-diphenyl-1-picrylhydrazyl (DPPH) and 2,2'-azino-bis(3-ethylbenzthiazoline-6sulfonic acid (ABTS) and correlation of total phenolic and flavonoid content with their inhibitory concentration 50 (IC S0 $_{50}$ of DPPH and IC s0 $_{\text {of }}$ ABTS.

Methods: Each sample was extracted by reflux using different polarity solvents. The extracts were evaporated using rotary evaporator. Antioxidant activities were tested using DPPH and ABTS assays, determination of total phenolic, and flavonoid content were carried out by ultraviolet-visible spectrophotometry and correlation with their $\mathrm{IC}_{50}$ of DPPH and IC ${ }_{50}$ of ABTS activities were analyzed by Pearson's method.

Results: The ethanolic leaves extract (LV3) of Simana lagi apple also exposed the highest total phenolic content (TPC) (13.88ggallic acid equivalents/100g), while the highest total flavonoid content was presented by ethyl acetate extract (LV2) $(7.21 \mathrm{~g} \mathrm{QE} / 100 \mathrm{~g})$. The lowest IC ${ }_{50}$ of DPPH scavenging activity $0.19 \mu \mathrm{g} / \mathrm{ml}$, and the lowest IC ${ }_{50}$ of ABTS scavenging activity $0.15 \mu \mathrm{g} / \mathrm{ml}$ was given by ethanolic flesh extract (FL3) of Simana lagi apple. There were significantly negative correlation between TPC in all different parts extracts of Simana lagi apple with their $\mathrm{IC}_{50}$ of DPPH and IC ${ }_{50}$ of ABTS.

Conclusions: All different parts extracts of Simana lagi apple were categorized as very strong antioxidant by DPPH and ABTS method (except n-hexane peels extract and n-hexane LV by DPPH method, and n-hexane FE by ABTS method). The major contributor in antioxidant activities of peels, flesh and leaves extracts of Simana lagi apple by DPPH and ABTS methods were phenolic compounds. Antioxidant activities of peels, flesh and leaves extracts of Simana lagi apple showed linear results by DPPH and ABTS methods.

Keywords: Antioxidant, 2,2-diphenyl-1-picrylhydrazyl, 2,2'-azino-bis(3-ethylbenzthiazoline-6-sulfonic acid, Simana lagi apple, Malus domestica.

(C) 2017 The Authors. Published by Innovare Academic Sciences Pvt Ltd. This is an open access article under the CC BY license (http://creativecommons. org/licenses/by/4. 0/) DOI: http://dx.doi.org/10.22159/ajpcr.2017.v10i11.20649

\section{INTRODUCTION}

Phenolic compounds are commonly used as subject of many researches. Phenolic compounds were produced by plant as defense mechanism against different stress condition. Phenolic compounds included flavonoid compounds have various effects such as antioxidant activity, antibacterial activity, antidiabetic, and hepatoprotector [1-4]. Antioxidant can prevent the excessive of free radical in oxidative stress condition which can cause many degenerative diseases. Fruits and vegetables are natural antioxidant because they contain phenolic and flavonoid compounds which have antioxidant capacity $[5,6]$. Simana lagi apple ([Malus domestica Borkh.] "Simana lagi") is one apple variety from Malang-East Java, Indonesia. The previous researches presented that apple contained many phenolic compounds such as quercetin, quercetin-3- galactoside, quercetin-3-glucoside, catechin, epicatechin, cyanidin-3-glucoside, and phloridzin $[7,8]$ which can act as antioxidant [9].

Some methods have been developed to determine antioxidant activity in many plants extracts such as 2,2-diphenyl-1-picrylhydrazyl (DPPH), ferric reducing antioxidant power (FRAP), and 2,2'-azinobis(3-ethylbenzthiazoline-6-sulfonic acid (ABTS) methods [10]. The previous studies [5,10-12] exhibited that DPPH, ABTS, and FRAP can be performed to determine antioxidant activity of fruits, vegetables and food.

The aims of this research were to observe antioxidant activities in various polarity extracts (n-hexane, ethyl acetate and ethanol) from different parts of Simana lagi apple grown in East Java-Indonesia using
DPPH and ABTS assays, and correlations of total phenolic and flavonoid content with their antioxidant activities.

\section{MATERIALS AND METHODS}

\section{Materials}

DPPH, ABTS diammonium salt, gallic acid, quercetin were purchased from Sigma-Aldrich (MO, USA), different parts of Simana lagi apple ([M. domestica Borkh.] "Simana lagi"). All of other reagents were analytical grades.

\section{Preparation of sample}

Different organs of Simana lagi apple (M. domestica) which were peels named as peels extract (PE), flesh as flesh extract (FL), and leaves as leaves extract (LV) were collected from Malang, East Java-Indonesia, were thoroughly washed with tap water, sorted while wet, cut, dried and grinded into powder.

\section{Extraction}

Crude drug was extracted by reflux using different polarity solvents. $300 \mathrm{~g}$ of crude drug was extracted by n-hexane as the first solvent and repeated three times. The remaining residue was then extracted three times using ethyl acetate as the second solvent, and finally, the remaining residue extracted three times using ethanol as the third solvent. Therefore totally, there were nine extracts: n-hexane PE (PE1), ethyl acetate PE (PE2), ethanolic PE (PE3), n-hexane FL (FL1), ethyl acetate FL (FL2), ethanolic FL (FL3), n-hexane LV (LV1), ethyl acetate LV (LV2), and ethanolic LV (LV3). Each extract was evaporated using rotary evaporator, and all extracts were prepared in similar density. 
Total flavonoid content (TFC)

Chang's method with minor modification was used to observe TFC [13]. The absorbance was measured at wavelength $415 \mathrm{~nm}$. Analysis was conducted in triplicate for each extract. Quercetin solution 50$125 \mu \mathrm{g} / \mathrm{ml}$ was used to obtain a calibration curve. TFC was demonstrated as percentage of total quercetin equivalent per $100 \mathrm{~g}$ extract ( $\mathrm{g} \mathrm{QE} / 100 \mathrm{~g}$ ).

\section{Total phenolic content (TPC)}

TPC was determined using Folin-Ciolcalteu reagent [14]. The absorbance was evaluated at wavelength $765 \mathrm{~nm}$. Analysis was performed in triplicate for each extract. Standard solution of gallic acid $(50-160 \mu \mathrm{g} / \mathrm{ml})$ was used to obtain a calibration curve. TPC was exposed as percentage of total gallic acid equivalent per $100 \mathrm{~g}$ extract (g gallic acid equivalents [GAE]/100 g).

\section{Antioxidant activity by DPPH assay}

Modification of Blois's method was used to observe antioxidant activity by DPPH [15]. $2 \mathrm{ml}$ of various concentration of each extract was added into $2 \mathrm{ml}$ DPPH solution $50 \mu \mathrm{g} / \mathrm{mL}$ to initiate the reaction for determining a calibration curve. The absorbance was observed after 30 minutes incubation at wavelength $515 \mathrm{~nm}$ by ultraviolet-visible (UVVis) spectrophotometer Beckman Coulter DU 720. Ascorbic acid was used as standard, DPPH solution $50 \mu \mathrm{g} / \mathrm{ml}$ as control and methanol as a blank. Analysis was observed in triplicate for standard and each extract. Antioxidant activity was evaluated by determining percentage of reduction of DPPH absorbance [16]. Inhibitory concentration 50\% $\left(\mathrm{IC}_{50}\right)$ of DPPH scavenging activity of each extract can be observed using its calibration curve.

\section{Antioxidant capacity by ABTS assay}

Minor modification of Li et al. [17] method was used to prepare ABTSsolution. Each solution of ABTS diammonium salt $7.6 \mathrm{mM}$ and potassium persulfate $2.5 \mathrm{mM}$ were prepared in aquadest and left in dark room for $12 \mathrm{hrs}$. The two solutions were mixed with 30 minutes incubation, left in refrigerator for $24 \mathrm{hrs}$, and then diluted in ethanol [18]. $2 \mathrm{ml}$ of various concentrations of each extract was added into $2 \mathrm{ml}$ ABTS solution $50 \mu \mathrm{g} / \mathrm{ml}$ to initiate the reaction for evaluating a calibration curve. The absorbance was read at wavelength $734 \mathrm{~nm}$ using UV-Vis spectrophotometer Beckman Coulter DU 720. Ascorbic acid was used as standard, ethanol (95\%) as a blank and ABTS solution $50 \mu \mathrm{g} / \mathrm{ml}$ as control. Analysis was conducted in triplicate for standard and each extract. Antioxidant capacity of each extract by ABTS method was evaluated by observing percentage of antioxidant activity using reduction of ABTS absorbance [16]. IC $_{50}$ of ABTS scavenging activity of each extract can be determined using its calibration curve.

\section{Statistical analysis}

Each sample analysis was performed in triplicate. All of presented results are means ( \pm standard deviation) of at least three independent experiments. Statistical analysis using ANOVA with a statistical significance level set at $\mathrm{p}<0.05$ and post hoc Tukey procedure was performed with SPSS 16 for Windows. Correlation between the total flavonoid and phenolic content and antioxidant activities and correlation between two antioxidant activity methods were performed using the Pearson's method.

\section{RESULTS}

\section{Density of different part extracts of Simana lagi apple}

The density of extract did not present in $100 \%$ concentrated extract, due to its difficult to determine density of concentrated extract using pycnometer; hence, the density of the extracts were reported as density $1 \%$ extract (Table 1 ).

\section{TFC in different parts extracts of Simana lagi apple}

TFC among three different parts extracts of Simana lagi apple were exhibited in term of quercetin equivalent using the standard curve equation $y=0.006 x-0.098, R^{2}=0.996$. TFC in different parts extracts of Simana lagi apple in the range of $0.66-7.21 \mathrm{~g} \mathrm{QE} / 100 \mathrm{~g}$. The lowest TFC (0.66 g QE/100 g) was given by ethanolic PE (PE3), while the highest
TFC (7.21 g QE/100 g) for ethyl acetate LV of Simana lagi apple (LV2) (Fig. 1).

\section{TPC in different parts extracts of Simana lagi apple}

TPC among different parts extracts of Simana lagi apple was reported in term of gallic acid equivalent using the standard curve equation $y=0.004 x+0.055, R^{2}=0.997$. TPC in three parts extracts of Simana lagi apple had different results varied from 0.60 to $13.88 \mathrm{~g} \mathrm{GAE} / 100 \mathrm{~g}$ (Fig. 2). N-hexane LV of Simana lagi apple gave the lowest TPC $(0.60 \mathrm{~g}$ GAE/100 g), while ethanolic LV of Simana lagi apple (LV3) had the highest TPC (13.88 g GAE/100 g).

\section{Antioxidant activity by DPPH and ABTS assays}

Antioxidant activity in different parts extracts of Simana lagi apple by $\mathrm{DPPH}$ and ABTS assays were conducted by calculating $\mathrm{IC}_{50}$ of DPPH and ABTS scavenging activities. IC $\mathrm{C}_{50}$ of DPPH and ABTS scavenging activities of each extract were compared to $\mathrm{IC}_{50}$ of ascorbic acid as standard. The lowest value of $\mathrm{IC}_{50}$ or $\mathrm{EC}_{50}$ means the highest antioxidant activity.

Correlations between total phenolic, flavonoid content in different parts extract of Simana lagi apple, $\mathrm{IC}_{50}$ of DPPH and $\mathrm{IC}_{50}$ of ABTS scavenging activities

TPC in all of different parts extract of Simana lagi apple had a significant and negative correlation with their $\mathrm{IC}_{50}$ of DPPH and $\mathrm{IC}_{50}$ of ABTS scavenging activities. TFC in LV s of Simana lagi apple showed negative and significant correlation with their $\mathrm{IC}_{50}$ of DPPH and IC $\mathrm{I}_{50}$ of

Table 1: Density of different part extracts of Simana lagi apple

\begin{tabular}{llll}
\hline Sample & \multicolumn{3}{l}{ Density 1\% extract $(\mathrm{g} / \mathrm{ml})$} \\
\cline { 2 - 4 } & N-hexane extract & $\begin{array}{l}\text { Ethyl acetate } \\
\text { extract }\end{array}$ & Ethanol extract \\
\hline Peels & 0.665 & 0.893 & 0.803 \\
Flesh & 0.664 & 0.891 & 0.801 \\
Leaves & 0.665 & 0.892 & 0.801 \\
\hline
\end{tabular}

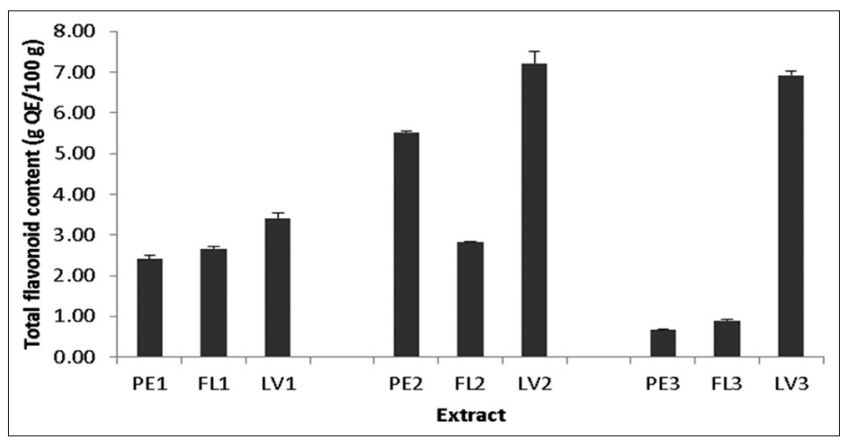

Fig. 1: Total flavonoid content in different parts extracts of Simana lagi apple $(n=3)$

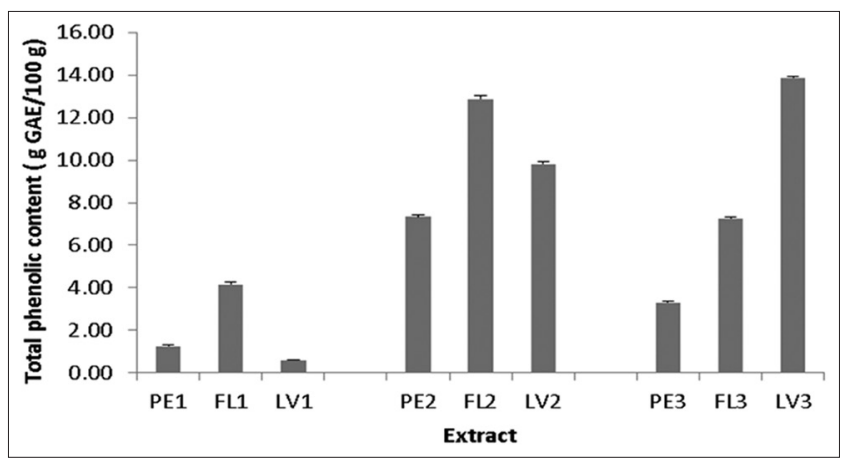

Fig. 2: Total phenolic content in different parts extracts of Simana lagi apple $(n=3)$ 
ABTS scavenging activities ( $r=-0.993 ; \mathrm{r}=-0.985, \mathrm{p}<0.01$, respectively) (Table 2).

\section{DISCUSSION}

The previous researches $[19,20]$ revealed that apple (M. domestica) had antioxidant capacity. There was no research regarding antioxidant activity of different parts of Simana lagi apple ([M. domestica Borkh.] "Simana lagi") which were peels, flesh and leaves which extracted using increasing polarity solvents (n-hexane, ethyl acetate and ethanol) and observed by DPPH and ABTS assays.

It is important when one study will compare the activities among the extracts and measure their phytochemical content to prepare the extract in similar density. One extract with high density may show the higher activity and the higher phytochemical content than low-density extract. All extracts (nine extracts) which were used in the present study prepared in similar density.

DPPH is free radical. DPPH in methanol exhibits the purple color and give absorption at wavelength $516 \mathrm{~nm}$. DPPH will stable when antioxidant transfer the hydrogen to DPPH to scavenge the free radical. Colors of DPPH will be changed from purple to yellow when the free radicals were scavenged by antioxidant [17]. The ability of antioxidant to scavenge the free radical DPPH has relationship with decreasing in absorption of DPPH. Concentration of sample or standard that can inhibit $50 \%$ of DPPH radical activity is called $\mathrm{IC}_{50}$ of DPPH scavenging activity. The highest antioxidant activity was demonstrated by the lowest $\mathrm{IC}_{50} . \mathrm{IC}_{50}$ was used to determine antioxidant activity of the sample was compared to standard.

ABTS diammonium salt is salt form of ABTS. ABTS is not soluble in water and polar solvent. So for determining antioxidant activity using ABTS assay should use ABTS diammonium salt. ABTS method is the same as TEAC method. TEAC is Trolox equivalency antioxidant capacity, which antioxidant activity was presented as Trolox equivalent. Sample which has higher Trolox equivalent value means higher antioxidant. Modification in ABTS assay was developed by Fidrianny et al. [18], and antioxidant activities did not express by Trolox equivalent, but using $\mathrm{IC}_{50}$ of ABTS scavenging activity and compared to ascorbic acid as standard.

ABTS is not free radical. The free radical will be formed after ABTS reacting with potassium persulfate and it will give blue color and has maximum wavelength at $734 \mathrm{~nm}$. Antioxidant will scavenge the free radical. The ability of antioxidant can be seen which related with decreasing in absorbance of the free radical.

$\mathrm{IC}_{50}$ of DPPH and $\mathrm{IC}_{50}$ of ABTS scavenging activities in different parts extracts of Simana lagi apple were demonstrated in Figs. 3 and 4. The $\mathrm{IC}_{50}$ of DPPH and $\mathrm{IC}_{50}$ of ABTS scavenging activities in different parts extracts of Simana lagi apple was compared to $\mathrm{IC}_{50}$ of ascorbic acid standard. The lowest value of $\mathrm{IC}_{50}$ means the highest antioxidant activity. Sample which had an $\mathrm{IC}_{50}$ lower than $50 \mu \mathrm{g} / \mathrm{ml}$ was a very strong antioxidant, $50-100 \mu \mathrm{mg} / \mathrm{ml}$ was a strong antioxidant, $101-150 \mu \mathrm{g} / \mathrm{ml}$ was a medium antioxidant, while a weak antioxidant with $\mathrm{IC}_{50}<150 \mu \mathrm{g} / \mathrm{ml}[15]$.

The previous study regarding antioxidant activities of 15 genotypes of apple from Pakistan [20] stated that aqueous fruit extract of golden delicious apple $1000 \mu \mathrm{g} / \mathrm{ml}$ gave the highest percentage of DPPH scavenging activity compared to the other genotypes, while the highest total antioxidant activity $(195.1 \mu \mathrm{g} / \mathrm{ml})$ using phosphomolybdenum reduction assay was shown by genotype-A apple $100 \mu \mathrm{g} / \mathrm{ml}$. The other previous research [19] revealed that water fruit extract (except seeds) from four apple cultivars which were Hossain, Sayyed Babaeei, Shekareh, Golab cultivars from Iran had different results in antioxidant activities using DPPH method and beta-carotene bleaching method. The water fruit extract of Hossain apple cultivar $2 \mathrm{mg} / \mathrm{ml}$ demonstrated that the highest percentage of DPPH scavenging activity (63.92\%), and the highest percentage of beta-carotene bleaching (6.02\%) compared to the other cultivars. This study exposed that ethanolic FL of Simana lagi apple had the highest antioxidant activity which showed by the lowest $\mathrm{IC}_{50}$ of DPPH $(0.19 \mu \mathrm{g} / \mathrm{ml})$ and the lowest IC of $_{50}$ ABTS $(0.15 \mu \mathrm{g} / \mathrm{ml})$. It is better when antioxidant activity presented in $\mathrm{IC}_{50}$ which concentration

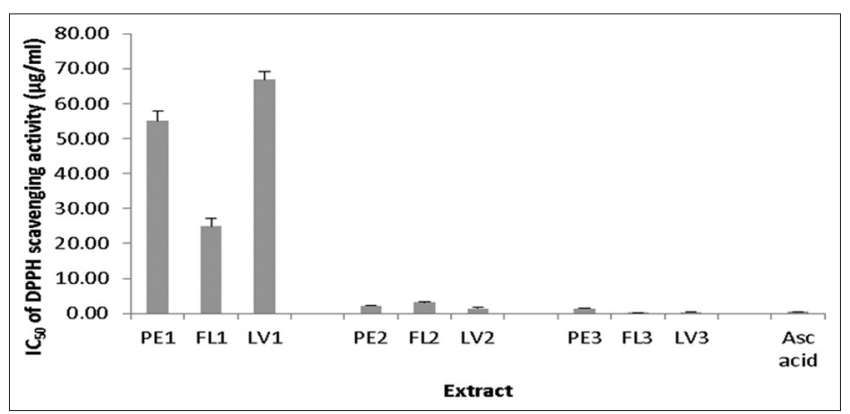

Fig. 3: Antioxidant activities of different parts extracts of Simana lagi apple by 2,2-diphenyl-1-picrylhydrazyl assay $(n=3)$

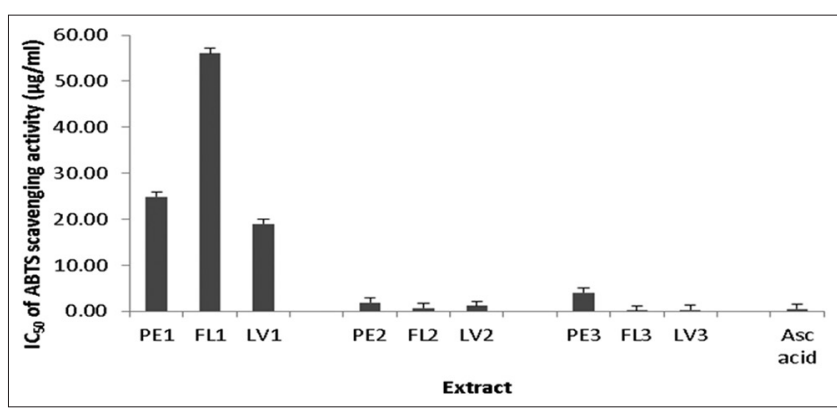

Fig. 4: Antioxidant activities of different parts extracts of Simana lagi apple by 2,2'-azino-bis(3-ethylbenzthiazoline-6-sulfonic acid assay $(n=3)$

Table 2: Pearson's correlation coefficient of total phenolic, flavonoid content in different parts extracts of Simana lagi apple with their $\mathrm{IC}_{50}$ of DPPH and $\mathrm{IC}_{50}$ of ABTS scavenging activities

\begin{tabular}{|c|c|c|c|c|c|}
\hline \multirow[t]{2}{*}{ Antioxidant parameter } & \multicolumn{5}{|c|}{ Pearson's correlation coefficient (r) } \\
\hline & TFC & TPC & $\mathrm{IC}_{50}$ ABTS PE & IC $_{50}$ ABTS FL & IC $_{50}$ ABTS LV \\
\hline $\mathrm{IC}_{50}$ DPPH PE & $-0,149 \mathrm{~ns}$ & $-0,748^{*}$ & $0,994^{* *}$ & & \\
\hline $\mathrm{IC}_{50}^{\mathrm{S0}} \mathrm{DPPH} \mathrm{FL}$ & $0,523 \mathrm{~ns}$ & $-0,693^{*}$ & & $0,986^{* *}$ & \\
\hline $\mathrm{IC}_{50}^{50} \mathrm{DPPH} \mathrm{LV}$ & $-0,993^{* *}$ & $-0,958^{* *}$ & & & $0,995^{* *}$ \\
\hline $\mathrm{EC}_{50}$ ABTS PE & $-0,246 \mathrm{~ns}$ & $-0,809^{* *}$ & & & \\
\hline $\mathrm{EC}_{50}^{50}$ ABTS FL & $0,436 \mathrm{~ns}$ & $-0,767 *$ & & & \\
\hline $\mathrm{EC}_{50} \mathrm{ABTS} \mathrm{LV}$ & $-0,985^{* *}$ & $-0,963^{* *}$ & & & \\
\hline
\end{tabular}

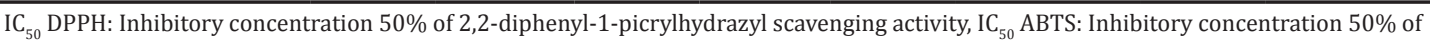

2,2'-azino-bis (3-ethylbenzthiazoline-6-sulfonic acid scavenging activity, PE: Peels of Simana lagi apple, FL: Flesh of Simana lagi apple, LV: Leaves of Simana lagi apple,

TPC: Total phenolic content, TFC: Total flavonoid content, ns: Not significant, ${ }^{*}$ significant at $\mathrm{p}<0.05,{ }^{* *}$ significant at $\mathrm{p}<0.01$ 
of extract or sample that can inhibit or scavenge $50 \%$ of the free radical. The percentage of DPPH scavenging activity did not always linear with increasing in concentration of extract. It can be seen that aqueous fruit extract of golden delicious apple, star king apple, royal gala apple, genotype B apple, kala kalu apple, and spartan apple at concentration of $100 \mu \mathrm{g} / \mathrm{ml}$ gave the lower percentage of DPPH scavenging activity than $50 \mu \mathrm{g} / \mathrm{ml}[20]$.

Antioxidant activity of extract can also be expressed in standard equivalent such as Trolox equivalent and ascorbic acid equivalent. Research by Wolfe et al. [21] regarding antioxidant activities of flesh, flesh+peels, and peels of four varieties of apple from New York reported that antioxidant of acetone PE of Idared varieties gave the highest antioxidant activity $(312 \mu \mathrm{mol}$ ascorbic acid equivalent/g of peels) compared to its $\mathrm{FL}$, flesh+PE and the other varieties. Liaudanskas et al. [22] revealed that 70\% ethanol LV of four apple cultivars (Aldas, Auksis, Ligol, and Lodel) from Lithuania showed different result in antioxidant activities by DPPH, ABTS, and FRAP assays. $70 \%$ ethanolic LV of Aldas apple cultivar presented the highest antioxidant activity using DPPH, ABTS, and FRAP methods. Its antioxidant activities using DPPH assay (142 $\mu \mathrm{mol}$ Trolox equivalent/g dry weight) was different from ABTS assay (280 $\mu \mathrm{mol}$ Trolox equivalent/g dry weight). It was similar to the present study which exposed that antioxidant activity of three parts (peels, flesh, and leaves) of Simana lagi apple showed different result in DPPH method and ABTS method. The $\mathrm{IC}_{50}$ of DPPH of ethanolic peels, flesh and LV of Simana lagi apple were 1.49, 0.19 and $0.37 \mu \mathrm{g} / \mathrm{ml}$, respectively, while their IC $_{50}$ of ABTS were $4.06,0.15$ and $0.25 \mu \mathrm{g} / \mathrm{ml}$, respectively.

Some researchers expressed that DPPH and ABTS methods have the same mechanism. Different results between DPPH and ABTS doe to their ability is different. ABTS radical can soluble in polar and non polar solvents, so it can use to determine antioxidant activity of hydrophilic and lipophilic compounds. DPPH radical soluble in polar solvent, hence only hydrophilic compound can be observed by DPPH method [23,24]. Based on the statement above, antioxidant activity using ABTS assay will give higher antioxidant than DPPH assay. However, it was contrary with this study, which ABTS assay did not always give higher antioxidant activity (lower IC ${ }_{50}$ of ABTS) than DPPH assay. The IC ${ }_{50}$ ABTS of ethanolic PE of Simana lagi apple $(4.06 \mu \mathrm{g} / \mathrm{ml})$ exposed the lower antioxidant activity than its $\mathrm{IC}_{50}$ of DPPH $(1.49 \mu \mathrm{g} / \mathrm{ml})$.

Apak et al. [25] demonstrated that two types of reaction in vitro antioxidant capacity, which is single electron transfer (SET) based assay and hydrogen atom transfer (HAT) based assay. SET based on the ability of antioxidant to transfer one electron to reduce oxidant, while HAT is based on the ability of antioxidant to quench radical by hydrogen donation [26]. The degree of color change (either increase or decrease of absorbance of the probe at a given wavelength) is affected by concentration of antioxidant [25]. SET and HAT mechanism almost always occur together, and mechanism that appears predominantly is influenced by ionization potential $(\Delta \mathrm{IP})$, bond dissociation energy (BDE), redox potential, $\mathrm{pH}$, and solvent $[25,26]$. SET mechanism is predominantly for compound with $\Delta \mathrm{IP}>-45 \mathrm{kcal} / \mathrm{mol}$ and HAT mechanism for compound with $\triangle \mathrm{BDE}$ of $\sim 10 \mathrm{kcal} / \mathrm{mol}$ and $\Delta \mathrm{IP}<-36$ $\mathrm{kcal} / \mathrm{mol}$ [26]. Therefore, the results of antioxidant activity using ABTS was not always higher than DPPH, it depends on $\triangle \mathrm{IP}, \mathrm{BDE}$, and redox potential of compounds in extract.

The presence of flavonoid and phenolic compounds can be related with antioxidant activities [14]. Study regarding total phenolic compuound (TPC) in water fruit extract (except seeds) from 4 apple cultivars from Iran reported that Golab apple cultivar showed the highest TPC (1.5 mg GAE/mg) compared to the other cultivars [19]. The previous research [21] exposed that acetone PE of Idared apple variety showed the highest TPC (599 mg GAE/100 g), compared to flesh and flesh+PEs and other varieties of apple, meanwhile acetone PE of rome beauty apple variety gave the highest TFC $306 \mathrm{mg} \mathrm{CE} / 100 \mathrm{~g}$, followed by Idared apple variety (303 mg CE/100 g). TPC in aqueous fruit extract in
Ammri apple genotype (1.21 g GAE/100 g) was the highest compared to the other genotypes, while the lowest TPC for royal gala apple genotype $(0.139 \mathrm{~g} \mathrm{GAE} / 100 \mathrm{~g}$ ) [20]. The previous study [22] expressed that $70 \%$ ethanol LV of Aldas apple cultivar showed the highest TPC (16.3 g GAE/100 g dry weight) and the highest TFC ( $4.5 \mathrm{~g}$ RE/100 g dry weight) compared to Auksis, Ligol and Lodel cultivars. It was similar to this study which revealed that TPC in ethanolic LV of Simana lagi apple (13.88 g GAE/100 g) and its TFC ( $6.92 \mathrm{~g} \mathrm{QE} / 100 \mathrm{~g})$ were the highest value compared to other parts (peels and flesh).

Scalbert and Williamson [27] exposed that there were many phenolic compounds in apple, such as chlorogenic acid, p-coumaric acid, quercetin, anthocyanidin, cyanidin-3-o-galactoside, catechin, epicatechin, and dihydrochalcone glycosides $[7,8]$. The previous result [9] demonstrated that quercetin-3-galactoside, quercetin-3glucoside, and cyanidin-3-glucoside can give high antioxidant activity.

In Fig. 1, it could be seen that TPC in ethyl acetate FL of Simana lagi apple (FL2) $12.86 \mathrm{~g} \mathrm{GAE} / 100 \mathrm{~g}$ was higher than TPC in ethanolic FL (FL3) $7.26 \mathrm{~g} \mathrm{GAE} / 100 \mathrm{~g}$, but FL3 had higher antioxidant activity which showed by lower $\mathrm{IC}_{50}$ of DPPH of $(0.19 \mu \mathrm{g} / \mathrm{ml})$ than FL2 $(3.13 \mu \mathrm{g} / \mathrm{ml})$. It can be supposed that many phenolic compounds in FL2 have low antioxidant activity, while FL3 contains many phenolic compounds which have high antioxidant activity.

Mechanism of flavonoid in antioxidant activity may be as single oxygen transfer, singlet oxygen quencher, hydrogen-donating compound, and metal chelating ion [28]. Flavonoid which has ortho di-OH at C3'-C4', double bond at $\mathrm{C} 2$ and $\mathrm{C} 3, \mathrm{OH}$ at $\mathrm{C} 3$ and 4 oxo function will give high antioxidant activity. Ortho di-OH at $\mathrm{C}^{\prime}-\mathrm{C}^{\prime}$ ' has highest influence in antioxidant activity [29]. TFC in n-hexane FL of Simana lagi apple (FL1) $2.66 \mathrm{~g} \mathrm{QE} / 100 \mathrm{~g}$ was similar to TFC in ethyl acetate FL (FL2) $2.88 \mathrm{~g}$ $\mathrm{QE} / 100 \mathrm{~g}$, but IC $\mathrm{I}_{50}$ of DPPH of FL1 $(24.85 \mu \mathrm{g} / \mathrm{ml})$ was higher than $\mathrm{IC}_{50}$ of DPPH of FL2 $(3.13 \mu \mathrm{g} / \mathrm{ml})$. Based on the result it can be predicted that many flavonoid compounds in FL2 have high antioxidant activity such as quercetin which has ortho di $\mathrm{OH}$ at $\mathrm{C}^{\prime}$ '- $\mathrm{C} 4$ '. In TFC determination, the positive reaction will be given by flavonoid which has ortho di - $\mathrm{OH}$ at $\mathrm{C} 3^{\prime}-\mathrm{C} 4$ ', -OH at $\mathrm{C} 3-$ oxo function at $\mathrm{C} 4$ and or $-\mathrm{OH}$ at $\mathrm{C} 5$ - oxo function at C4. Aluminum (III) chloride in TFC determination can react with any compound which has ortho di $\mathrm{OH}$ at benzene ring and form complex. The reaction can be occurred in any compound which has ortho di $-\mathrm{OH}-\mathrm{OCH}_{3}$ in benzene ring, which may be soluble in n-hexane and give the higher TFC value in $n$-hexane extract.

TPC in n-hexane LV of Simana lagi apple (LV1), ethyl acetate LV (LV2), and ethanolic LV (LV3) was $0.60 \mathrm{~g}$ GAE $/ 100 \mathrm{~g}$, $9.82 \mathrm{~g} \mathrm{GAE} / 100 \mathrm{~g}$, and $13.88 \mathrm{~g}$ $\mathrm{GAE} / 100 \mathrm{~g}$, respectively, meanwhile their $\mathrm{IC}_{50}$ of DPPH scavenging activities were $66.83 \mu \mathrm{g} / \mathrm{ml}, 1.49 \mu \mathrm{g} / \mathrm{ml}$, and $0.37 \mu \mathrm{g} / \mathrm{ml}$, respectively. The similar result was exposed in ABTS assay, which exhibits their IC $_{50}$ of ABTS scavenging activities $56.09 \mu \mathrm{g} / \mathrm{ml}, 1.18 \mu \mathrm{g} / \mathrm{ml}$, and $0.25 \mu \mathrm{g} / \mathrm{ml}$, respectively. Based on the data, it can be seen that the higher TPC gives the higher antioxidant activity, which shows by the lower $\mathrm{IC}_{50}$ of DPPH and $\mathrm{IC}_{50}$ of ABTS scavenging activity.

These data can also be explained by determining correlation coefficient of TPC, IC $\mathrm{I}_{50}$ DPPH and $\mathrm{IC}_{50}$ of ABTS. Statistical analysis was performed using Pearson's correlation coefficient. Coefficient of Pearson correlation was significantly negative if $-0.61 \leq r \leq-0.97$ and significantly positive if $0.61 \leq r \leq 0.97$ [11]. The good correlation was negative and significant correlation [30]; hence, the higher TPC or TFC will give the lower $\mathrm{IC}_{50}$ of DPPH or $\mathrm{IC}_{50}$ of ABTS scavenging activities. The result of Pearson's correlation coefficient showed that TPC in Simana lagi apple LVs was significantly negative and high correlation with their $\mathrm{IC}_{50}$ of DPPH and $\mathrm{IC}_{50}$ of ABTS ( $\left.\mathrm{r}=-0.958, \mathrm{r}=-0.963, \mathrm{p}<0.01\right)$, while apple PE and apple FL gave the lower correlation. TPC in Simana lagi apple FL and LV were significantly negative correlation with their $\mathrm{IC}_{50}$ of DPPH ( $\mathrm{r}=-0.748, \mathrm{r}=-0.693, \mathrm{p}<0.05$, respectively) and their $\mathrm{IC}_{50}$ of ABTS $(r=-0.809, r=-0.767, p<0.01$, respectively). Phenolic compounds were the major contributor in antioxidant activities of flesh and LVs of 
Simana lagi apple by DPPH and ABTS methods. The two antioxidant testing methods showed a significant and positive correlation in antioxidant activities of peels, flesh and LVs of Simana lagi apple.

\section{CONCLUSIONS}

Different results in antioxidant activities can be given by various methods, so antioxidant activities should be performed by different methods in parallel. All different parts extracts of Simana lagi apple ([M. domestica Borkh.] "Simana lagi") can be categorized as very strong antioxidant using DPPH assay (except n-hexane PE and n-hexane LV) and using ABTS assay (except n-hexane FL). Phenolic compounds in peels and FLs of Simana lagi apple were the major contributor in their antioxidant activity by DPPH and ABTS methods. There was linear correlation between $\mathrm{IC}_{50}$ of DPPH scavenging activities and $\mathrm{IC}_{50}$ of ABTS scavenging activities in all parts extracts of Simana lagi apple (peels, flesh and leaves). Peels, flesh and leaves of Simana lagi apple ([M. domestica Borkh.] "Simana lagi") have potential as sources of natural antioxidant for further exploitation.

\section{ACKNOWLEDGMENT}

This work was funded by Research, Community Service and Innovation Program for Research Group. The authors are grateful for Institute for Research and Community Service - Bandung Institute of Technology.

\section{REFERENCES}

1. Kobori M, Masumoto S, Akimoto Y, Oike H. Phloridzin reduces blood glucose levels and alters hepatic gene expression in normal balb/c mice. Food Chem Toxicol 2012;50(7):2547-53.

2. Ohta T, Morinaga HT, Yamamoto T, Yamada T. Effect of phlorizin on metabolic abnormalities in spontaneously diabetic torii (SDT) rats. Open J Anim Sci 2012;2(2):113-8.

3. Mokbel MS, Hashinaga F. Antibacterial and antioxidant activities of banana (Musa, AAA cv. Cavendish) fruits peel. Am J Biochem Biotechnol 2005;1(3):125-31.

4. Sebei K, Gnouma A, Herchi W, Sakouhi F, Boukhchina S. Lipids, proteins, phenolic composition, antioxidant and antibacterial activities of seeds of peanuts (Arachis hypogaea $\mathrm{L}$ ) cultivated in Tunisia. Biol Res 2013;46(3):257-63.

5. Pellegrini N, Serafini M, Colombi B, Del Rio D, Salvatore S, Bianchi M, et al. Total antioxidant capacity of plant foods, beverages and oils consumed in Italy assessed by three different in vitro assays. J Nutr 2003;133(9):2812-9.

6. Kandoliya UK, Bajaniya VK, Bhadja NK, Bodar NP, Golakiya BA. Antioxidant and nutritional components of egg plant (Solanum melongena L.) fruit grown in Saurastra region. Int J Curr Microbiol Appl Sci 2015;4(2):806-13.

7. Vrhovsek U, Rigo A, Tonon D, Mattivi F. Quantitation of polyphenols in different apple varieties. J Agric Food Chem 2004;52(21):6532-8.

8. Cuthbertson D, Andrews PK, Reganold JP, Davies NM, Lange BM. Utility of metabolomics toward assessing the metabolic basis of quality traits in apple fruit with an emphasis on antioxidants. J Agric Food Chem 2012;60(35):8552-60.

9. Wilson AM, Vazquez ME, Arredondo SI, Plascencia AE, Burgueno MR, Rios HG, et al. Potential of polyphenols from an aqueous extract of apple peel as inhibitors of free radicals: An experimental and computational study. J Mol Struct 2013;1035:61-8.

10. Thaipong K, Boonprakob U, Crosby K, Zevallos LC, Byrne DH.
Comparison of ABTS, DPPH, FRAP, and ORAC assays for estimating antioxidant activity from guava fruit extracts. J Food Compost Anal 2006;19:669-75.

11. Settharaksa S, Madaka F, Chakree K, Charoenchai L. Total phenolic and flavonoid contents and antioxidant properties of Thai traditional herbal. Int J Pharm Pharm Sci 2014;6(9):564-6.

12. Arya N, Prakash OM, Verma AK, Vivekanand, Pant AK. Variation in antioxidant potential of Curcuma longa L. Collected from different ecological niches of Western Himalayan region. Int J Pharm Pharm Sci 2015;7(7):85-90.

13. Chang CC, Yang MH, Wen HM, Chern JC. Estimation of total flavonoid content in propolis by two complementary colorimetric methods. J Food Drug Anal 2002;10(3):178-82.

14. Pourmorad F, Hosseinimehr SJ, Shahabimajd N. Antioxidant activity, phenol and flavonoid content of some selected Iranian medicinal plants. Afr J Biotechnol 2006;5(11):1142-5.

15. Blois MS. Antioxidant determination by the use of stable free radicals. Nature 1958;181:1199-2000.

16. Bedawey AA. Characteristics of Antioxidant Isolated from Some Plants Sources. Shibin El-Kom, Cairo: Shams University; 2010. p. 1-11.

17. Li XC, Wang XZ, Chen DF, Chen SZ. Antioxidant activity and mechanism of protochatechuic acid in vitro. J Funct Food Health Dis 2011;1(7):232-44

18. Fidrianny I, Windyaswari AS, Wirasutisna KR. Antioxidant capacities of various leaves extract from five colors varieties of sweet potatoes tubers using ABTS, DPPH assays and correlation with total flavonoid, phenolic, carotenoid content. Res J Med Plant 2013;7(3):130-40.

19. Jelodarian S, Ebrahimabadi A, Khalighi A, Batooli H. Evaluation of antioxidant activity of Malus domestica fruit extract from Kashan area. Afr J Agric Res 2015;10(20):2136-40.

20. Maqsood A, Sabir SM, Qaisar M, Riaz M. Nutritional analysis and in-vitro antioxidant activity of apple (Malus domestica). J Food Agric Environ 2013;11(3-4):168-72.

21. Wolfe K, Wu X, Liu RH. Antioxidant activity of apple peels. J Agric Food Chem 2003;51(3):609-14.

22. Liaudanskas M, Viškelis P, Raudonis R, Kviklys D, Uselis N, Janulis V. Phenolic composition and antioxidant activity of Malus domestica leaves. ScientificWorldJournal 2014;2014:306217.

23. Floegel A, Kim DO, Chung SJ, Koo SI, Chun OK. Comparison of ABTS/DPPH assays to measure antioxidant capacity in popular antioxidant-rich US foods. J Food Compost Anal 2011;24(7):1043-8.

24. Minioti KS, Georgiou CA. Comparison of different tests used in mapping the Greek virgin olive oil production for the determination of its total antioxidant capacity. Grasas Y Aceites 2010;61(1):45-51.

25. Apak R, Gorinstein S, Böhm VK, Schaich MK. Methods of measurement and evaluation of natural antioxidant capacity/activity: IUPAC technical report. Pure Appl Chem 2013;85(5):957-98.

26. Prior RL, Wu X, Schaich K. Standardized methods for the determination of antioxidant capacity and phenolics in foods and dietary supplements. J Agric Food Chem 2005;53(10):4290-302.

27. Scalbert A, Williamson G. Dietary intake and bioavailability of polyphenols. J Nutr 2000;130 8S Suppl:2073S-85.

28. Amic D, Davidovic-Amic D, Beslo D, Rastija V, Lucic B, Trinajstic N. SAR and QSAR of the antioxidant activity of flavonoids. Curr Med Chem 2007;14(7):827-45.

29. Heim KE, Tagliaferro AR, Bobilya DJ. Flavonoid antioxidants: Chemistry, metabolism and structure-activity relationships. J Nutr Biochem 2002;13(10):572-84.

30. Fidrianny I, Johan Y, Sukrasno. Antioxidant activities of different polarity extracts from three organs of makrut lime (Citrus hystrix DC) and correlation with total flavonoid, phenolic, carotenoid content. Asian J Pharm Clin Res 2015;8(4):239-43. 